\title{
The Diversity of Ecotourism Potentials in Kelimutu National Park of Ende Regency
}

\author{
Josef A. Gadi Djou ${ }^{1}$, M. Baiquni' ${ }^{2}$, Tri Widodo ${ }^{3}$ and C. Fandeli ${ }^{4}$ \\ ${ }^{1}$ Flores University, Indonesia \\ ${ }^{2,3,4}$ Gadjah Mada University, Indonesia
}

Corresponding author: josefgadidjou271071@gmail.com

\begin{abstract}
ARTICLE INFO
ABSTRACT

Received

20 March 2016

Accepted

30 August 2016

Available online

15 September 2016

Natural tourist destination management plays a crucial role in materializing three important aspects, namely conservation, participation, and education. As a tourist destination, Kelimutu National Park, possessing a big ecosystem potential, tourist and cultural potentials, is expected to provide economy, culture, and conservation impacts on the society surrounding Kelimutu National Park. The problem of this study is how the variety of ecotourism potential in Kelimutu National Park is able to prosper the surrounding society. To answer this question, the definition of ecotourism, national park, national park ecotourism, and ecotourism potential need to be understood. Several methods used in answering the problems of the study are finding out the location of Kelimutu National Park, collecting qualitative data by conducting library research and participatory observation. The results were conceptually described, supported by tables and pictures.
\end{abstract}

Keywords: natural tourist destination, tourism potential, ecotourism

\section{Introduction}

\section{Background}

It is not an impossible task for local community in a tourist attraction to maintain the ecosystem, to keep the environment, and to provide education on environment (Page and Dowling, 2001:59). This is called ecotourism. Society involvement in keeping the environment of natural tourist destination is expected to make the tourist destination well maintained with its local wisdom. Tourism sector is one of important components in national economy development. Since 1980s and 1990s, this sector has contributed the third biggest foreign exchange for the country of the total export preceded by gas, oil, and wood materials. In order to optimize the contribution of this sector toward national economy development, integrated patterns of planning and management in all sectors are continuously needed. This is because the commodities of tourism sector are closely related with other sectors. For that reason, the support and linkage between these sectors are required for its continuity and preservation (Direktur Jendral Pengembangan Destinasi Pariwisata, 2010).

The sectors of agriculture, economy, trade, social, culture, forestry, and fishery synergisticallycontributeto integrated tourism. They are proven to be the resources of tourist destination which are regarded to be primary attractions of all tourism resources. Thus, the management of tourist destination heavily depends on three elements, namely a) The excellency and attractions of tourist destination for tourism markets; b) Its benefits for the resources of ecology, economy, social, and culture of a region; c) The capability to compete with other tourists destination in international tourism markets (Damanik and Teguh, 2012). 
The dependency on the above mentioned elements cover all forms of tourist destinations, including the natural one (or frequently called ecotourism). As seen in ecotourism development, touring to natural destination can be categorized into different groups in line with its objectives and activities. People can visit natural tourist destination for the sake of experiencing natural life, participating in nature preservation, and benefitting from the natural education. This implies that natural tourism may at least cover three aspects, such as the preservation and sustainability of nature, active participation, and environmental education (Page and Dowling, 2001). In further circumstances, natural tourism can be one of human activities with recreational motivation based on the utilization of natural resources. As a part of human activities, natural tourism has economical, sociocultural, and environmental influences on either consumers or producers, and the society surroundings the tourist location, in terms of production, consumption, and the movement patterns. When linked to unique tourism characteristics, that is to say the production and consumption are in the same venues, its impact is mainly centered in tourist destination.

For the above reasons, natural tourist destination management plays an important role to manifest the previously mentioned elements of preservation, participation, and education. The expansion of tourist destination should involve those elements even though theaspects of economy, social, and environment have become the important components that need to be altogether achieved. It is commonly known that economy, socio, and environmental principles have indeed been integrated to color natural tourism development. In economy aspect, natural tourism has been proven to contribute to improvement of foreign exchangeand rough domestic product.In social aspect, natural tourism can absorb large human resources and to preserve traditional culture, such as art, custom, and local belief. As regard environmental aspect, natural tourism can promote the products of natural resources and fishery effectively in more globalized market (Nugroho, 2011:1).

http://ojs.unud.ac.id/index.php/eot
Based upon this fact, Muhamad (2010) asserts that currently natural tourism developmental perspectives have provided the opportunity to local society to actively participate in its management. Community involvement is considered important to specify natural tourism development due to current issues of local community participation as the efforts of preservation and sustainability. This perspective is called community based natural tourism development that is a point of view of natural tourism development involving the society in planning, decision making, management, and accountability in sustainable preservation.

Natural tourism produces approximately 12 billion US Dollars annually of global tourism income. Global tourism is the biggest industry and $10 \%$ world economy was contributed by tourism industry (Fennel as cited in Supriatna, 2014:1). As a natural tourist destination, Kelimutu National Park has big potentials of ecosystem, tourism, and culture expected to impact the surrounding community. The impacts are the well maintained environment, economical benefits, and the preserved culture related to Kelimutu National Park. The research problem in this study is in what way the diversity of ecotourism potentials in Kelimutu National Park can benefit local people.

According to The International Ecotourism Society (TIES) as quoted in Nugroho (2011), ecotourism is defined as a tour to natural areas in order to conserve and protect the environment and provide the incomes for local people. This idea is also defined by World Conservation Union (WCU), asserting that ecotourism is a tour to genuinely natural environment by respecting cultural and natural heritages, supporting conservation efforts, resulting positive impact, and socioeconomically benefiting local people participation. Recently, TIES and WCU definitions are referred and developed by many experts in analyzing ecotourism attitudes or implementation in any destination and country. Some of the experts are Page and Dowling (2001) and Fandeli (2002). In their analysis, it is revealed that there are 8 (eight) aspects of ecotourism tours are as follows: (1) the tour is based on natural resources; (2) the activities focus on the achievement of experience and education of nature; (3) the 
presence is able to contribute to conversation, preservation, and protection of environment; (4) in economy aspect, its implementation is able to socioeconomically benefit sustainably; (5)keep respecting and involving local people; (6) the tourist actively participate on it; (7) its implementation is sustainable and unconsumptive; (8) the tour is responsible for the managed condition of natural tourist destination.

Based on this analysis, the identified elements in ecotourism tour are in line with the ecotourism definition proposed by TIES and WCU. As asserted in The International Ecotourism Society (TIES) that the activities of ecotourism should be based on 5 main points, such as (1) every ecotourism activities should be addressed in enjoying the beauty of nature, enriching knowledge and understanding of various uniqueness of nature and culture; (2) the tour should be responsible for the entire natural components that become ecotourism objects; (3)ecotourist destination should be natural and well managed; (4) either the tourists and the management should have strong commitment in supporting conservation, preservation, and sustainability; (5) the existence of the tourist and its objects can enhance the income of local people. Ecotourism implementation in Indonesia should direct to TIES principles above for the purposes of (1) manifesting the accountable tourism management; (2) supporting the natural environment preservation, historical and cultural heritages; (3) improving community participation and providing advantages for local people; (4) becoming model of other tourism development through ecotourism characteristics.

It is expected that Indonesian people have the concern, responsibility, and commitment on environment preservation because this will influence the prosperity of society in general and local people in particular. It needs to be asserted earlier because in the perspective of Indonesian Government, there are some concern particularly related to the sustainability and preservation of nature that becomes the object of ecotourism. Several concerning issues are (a) the assumption of environmental damages due to huge exploration of natural resources; (b) the assumption of tourism requiring good

http://ojs.unud.ac.id/index.php/eot and healthy environment leading to huge nature exploration; (c) the preservation of environment cannot be done without active participation of local people; (d) the commitment of local people participation will not be without the local people benefitting economically from preserved environment; (e) the presence of tourist in natural tourist destination may not provide the opportunity for local people to have alternative income, for example by being tour guide, porter, having business of homestay, ecotourism lodges, restaurants, and other business related to ecotourism. These concerns may lead to the assumptions that the prospertity and life quality of local people may not be improved. Therefore, ecoutourism principles need to be upholding from now on so that the above mentioned concerns can be overcome and the implementation of ecotourism can bring the advantages of all parties sustainably.

The important principles emphasized by TIESand Indonesian Government have significant values in this research as they become the basis in observing Kelimutu National Park as an ecotourism destination more deeply. Will this destination be managed based on ecotourism characteristics or massal tourist object as others? The ecotourism principles proposed by TIES and Indonesian Government are helpful in identifying and mapping Kelimutu National Park as an ecotourist destination. In other words, this library research can guide the researcher in directing focusing on more essential matters of ecotourism in Kelimutu National Park. However, there is still one general principle, in other words, the perspective of natural based ecotourism object is not specific to particular ecology, but it is in the forms of common village, forest, mountain, or desert. Concerning the ecotourism locus in this research focuses on particular tourism object, Kelimutu National Park, the discussion of this issue needs to be earlier introduced. This is to provide clear overview of physical object of Kelimutu National Park so that there will be thorough and depth understanding of this research object material.

National Park is the best conserved area that provides the attractions about the diversity, uniqueness, endemic flora and fauna beauty, vanished and protected, including the 
beauty and magic of natural phenomena available in that national park. As generally known, national park is an area managed by the government with the purpose of the preservation and sustainability of diverse plants and animals as well as its ecosystem. This purpose is in line with Consitution Number 5, 1990 about Conservation of Natural Biodiversity and Its Ecosystem, outlining that national park is an area of natural conservation, either land or water having genuine ecosystem managed by zonal system for the purpose of research, science, education, cultivation and tourism. Thus, Nugroho (2011) claims that national park should have the consideration fundamentals, such as (a) having high potential of biodiversity, with unique flora and fauna in extinct condition; (b) being water absorption important for surrounding community; (c) having beautiful scenery with various natural tourism potentials, ecotourism in particular; (d) having potentials of interesting traditional and cultural attractions, including cites, historical buildings, and the improvement of society prosperity; (e) having potentials of education and research; (f) all are addressed to the purposes of protection, preservation, utilization of biodiversity resources and ecosystem.

With this in mind, Wiratno et al. (2004) provide general overview of national park consisting of several elements, namely (a) large areas of national park; (b) national park should contain particular veggies, animals, habitats, geomormology, original nature beauty; (c) there are effective systems of protection in which the ecosystem is physically unchanging due to the exploitation or housing activities; (d) competent central government should hold the policy and management, should take preventive actions or eliminate all hindrances or damages on ecosystem and the national park contents; (e) the possibility of tourism development allowing visitors entering the park with special requirements for the sake of finding inspiration, education, culture, and recreation.

It is the contention of (Nugroho, 2011) and Wiratno et al. (2004) that national park areas have disctinctive characteristics different to other conservation, particularly in terms of its total areas. The ecosystem in national park

http://ojs.unud.ac.id/index.php/eot is still wild, genuine, in the forms of primary and secondary forest, bush, savanna, beach, ocean, and mountain areas. For that reasons, national park areas need to be carefully preserved in order to protect them and the life of wild sanctuary can sustain and well grown. In fact, the management of national park has its hindrances. As noted in Wiratno et al. (2004), national park management in Indonesia has its drawbacks. The basic ones are (a) limited budget; (b) less qualified management resources; (c) inadequate infrastructure; (d) unoptimal interactions with local people. These drawbacks, according to Wiratno et al. (2004) also occur in other national park conservations, thus leading to the needs of better synergic managementresponsible for the improvement of its implementation. When carefully studied, crucial principles are enacted in this national park, not far from the imposing principles in ecotourism. In national park, there are enactments of genuine characteristics of the conserved objects, ongoing responsibility, protection and preservation, beneficial values for local people, local community participation, and can be further used for research, science, education, the development of cultivation and tourism. Hence, the understanding of national park ecotourism in this researchis basically the derivation of ecotourism principles proposed by TIES and Indonesian Government covering the principles imposement of national park conservation as asserted in Constitution Number 5, 1990 about The Conservation of Biodiversity Resources and Its Ecosystems.

Based on the considerations of the whole analysis of ecotourism and national park, national park ecotourism can be defined in this study as tours to national park area to enjoy, respect, and support the conservation of natural resources, either flora, fauna, or the culture to benefit local people socially and economically, and to enhance local community participation in preservation and prevention of natural characteristics damages of national park.Regarding its definition, it is not a new definition in ecotourism, but the narrowing natural aspects in general ecotourism. This research focuses only on specific object, namely national park. Therefore, national park defined here is limited on Kelimutu National Park. Positive 
impact of natural tourism is to protect the diversity of the nature and to fix natural damages in relation to comprehensive conservation management. The protection of the wild sanctuary can happen due to the substation of local people's income sources from animals hunting to tourism related jobs, such as accommodation providers, tour guides, and handicraft makers (Supriatna, 2014:3).

\section{Research Objectives}

Purpose of this research is to analyze the variety of ecotourism potential in Kelimutu National Park including geographical condition, the potentials of flora dan fauna, the potentials of social, economy and culture of local mommunity in Kelimutu National Park Areas as well as the potentials of river flow areas.

\section{Methodology}

Kelimutu National Park is located in 5 (five) sub-districts in Ende Regency, namely Ndona Sub-district, NdonaTimur Sub-district, Wolojita Sub-district, DetusokodanKelimutu Sub-districtcovering 26 villages, namely Wolomasi, Saga, Ndito, Niowula, Woloweo, Detusoko Barat, Detusoko, Wologai, Wologa Tengah, Sipijena, Nduaria, Nuamuri Barat, Nuamuri, Koanara, Woloara, Waturaka, Pemo, Wiwipemo, Tenda, Wolojita, Roga, Sokoria, Sokoria Selatan, Kurulimbu, Puutuga, Kelikiku. The research was conducted in Kelimutu Sub-district, particularly in four villages of Pemo, Koanara, Waturaka, andWoloara. These four villages were chosen to be studied due to their locations on nuclear zone of Kelimutu National Park. Data was analyzed by using descriptive qualitative methods through library research and participatory observation. The results of this research are conceptually described supported by tables and images.

\section{Results and Discussion}

\section{Geographical Condition}

The area of Kelimutu National Park is $5,356.5$ ha containing various natural resources, some of which are endemic. The dominant natural resources can be seen from the aspects of geology, flora fauna, and river flow areas that become water spring for the life of the park and local people. This resource can function as both the source of life for the surrounding habitats and potentially as research and tourism objects. Since 2007, this asset has been explored for those purposes.

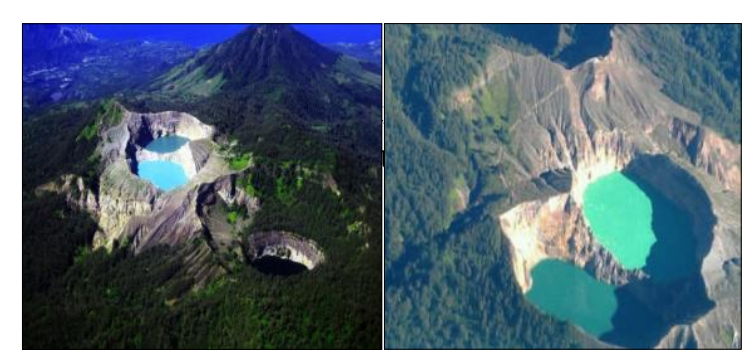

Figure 1. Lake Kelimutu

Turning to geological aspect, Kelimutu National Park consists of acid rocks, semi acid rocks, and kersik rocks, and effusive rocks(Ridwan (2001) in BTNK Team (2009)). The soil types are Regosol, Mediteran, Latosol and sandy as a result of volcano sediment from the mountains of Kelibara, KelimutuandSukoria. This potential makesKelimutu National Park as a fertile area suitable for growing trophical plants and catering animals.In addition to this, geological composition of Kelimutu National Park are constructed by the color lake, namely DanauTiwu Ata Mbupu (dark green),TiwuNuwa Muri Koo Fai (light green), and TiwuAtapolo (reddish brown). These three lakes locate in the area of Kelimutu National Park with the heights of 50 to 150 meter at the surface of Lake water level. Recently, these three lakes have been the natural tourist attraction along with its religious functions for local people.

\section{Potentials of Flora dan Fauna}

Regarding flora and fauna, Kelimutu National Park has various flora and fauna, some of which are extinct. According to the inventory of BTN Kelimutuand LIPI (2007), there are two endemic Kelimutu floras. They are presented in Table 1 below. 
Table 1

Types of Extinct Flora in Kelimutu National Park

\begin{tabular}{|c|c|c|c|}
\hline No & $\begin{array}{l}\text { Local } \\
\text { Name }\end{array}$ & Scientific Name & Status \\
\hline 1 & Uta Onga & $\begin{array}{c}\text { Begonia } \\
\text { Kelimutuensis }\end{array}$ & $\begin{array}{l}\text { Flores } \\
\text { endemic }\end{array}$ \\
\hline 2 & Turuwara & $\begin{array}{l}\text { Rhododendrom } \\
\text { Renschianum }\end{array}$ & $\begin{array}{l}\text { Flores } \\
\text { endemic }\end{array}$ \\
\hline 3 & Jita/Putai & $\begin{array}{l}\text { Alstonia } \\
\text { Scholaris }\end{array}$ & $\begin{array}{c}\text { almost } \\
\text { endangere } \\
\mathrm{d}\end{array}$ \\
\hline 4 & $\begin{array}{c}\text { Upe/Keti } \\
\text { mun }\end{array}$ & $\begin{array}{l}\text { Timonius } \\
\text { Timon }\end{array}$ & $\begin{array}{c}\text { almost } \\
\text { endangere } \\
\mathrm{d}\end{array}$ \\
\hline
\end{tabular}

Source: Kelimutu National Park Authority, 2009

The extinct existence of these floras needs to be concerned in Kelimutu National Park conservation area. This is because their existence is limited and available in particular zones only. In addition, illegal logging may influence the more becoming vanished flora populations in the zones. Consequently, the preventive actions through conservation need to be intensified to avoid the extinctions of the population.
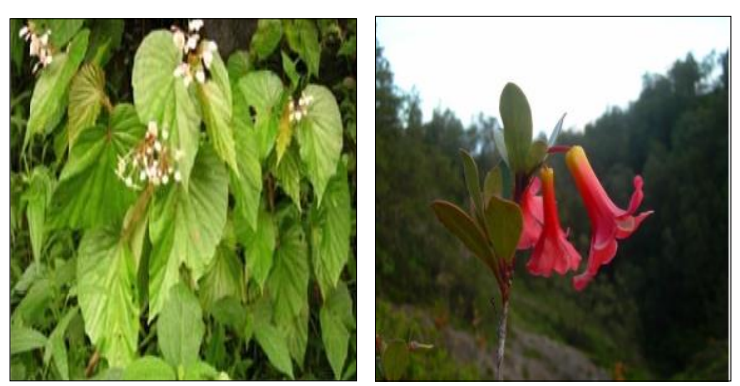

Figure 2. Type of Flora: Uta Onga (Begonia kelimutuensis) and Turuwara (Rhododendron renschianum)

Similar to this flora condition, Kelimutu National Park has several amount of endemic faunas that are nearly extinct. As pointed out in the research conducted by Balai Taman Nasional Kelimutu (2009), there is one endangered fauna, 1 (one) type of fauna in vurnerable condition, 1 (one) in minimal risk, 2 (two) in nearly vanished condition, and 8 (eight) types of Flores endemic. The complete information can be seen in the following Table 2.

Source: Kelimutu National Park Authority, 2009

In addition to the extinct faunas as in Table 2, Kelimutu National Park has also several types of birds (avifauna) in good conditions. They are the predatory birds, buzzard, grain and fish eaters, and honeyeaters (BTN Kelimutu and LIPI, 2007). On the top of DanauTiwu Ata Polo, eagles and other predators, such as Hieraaetusfasciatus, Hieraaetuskieneriiand Pernissp can be found. In other areas, there are 14 types of mammals consisting of 4 types of bats, 3 types or mouses, 1 type of mice, 1 type of apes, 1 type of civet, 2 types of wild boar, 1 type of porcupine, and 1 type of rats.

Types of Extinct Faunas in Kelimutu National Park

\begin{tabular}{|c|c|c|c|}
\hline No & Local Name & $\begin{array}{l}\text { Scientific } \\
\text { Name }\end{array}$ & Status \\
\hline \multirow[t]{2}{*}{1} & Pergam & Dukula & \multirow{3}{*}{$\begin{array}{l}\text { almost } \\
\text { endangered } \\
\text { almost } \\
\text { endangered }\end{array}$} \\
\hline & katanjar/lodo & Rosacea & \\
\hline 2 & $\begin{array}{l}\text { Sikatan dada } \\
\text { merah/singgi } \\
\text { wela }\end{array}$ & $\begin{array}{l}\text { Ficedula } \\
\text { Dmuetoria }\end{array}$ & \\
\hline 3 & $\begin{array}{l}\text { Cekakak } \\
\text { tunggir } \\
\text { putih/vengga }\end{array}$ & $\begin{array}{l}\text { Haleyon } \\
\text { Fulgida }\end{array}$ & $\begin{array}{l}\text { Flores } \\
\text { endemic }\end{array}$ \\
\hline 4 & $\begin{array}{l}\text { Opior paruh } \\
\text { tebal/Anake }\end{array}$ & $\begin{array}{l}\text { Halela } \\
\text { Crassirostris }\end{array}$ & $\begin{array}{l}\text { Flores } \\
\text { endemic }\end{array}$ \\
\hline 5 & $\begin{array}{l}\text { Opior } \\
\text { Jambul/anake }\end{array}$ & $\begin{array}{l}\text { Lophozoster } \\
\text { ps Duhertyi }\end{array}$ & $\begin{array}{l}\text { Flores } \\
\text { endemic }\end{array}$ \\
\hline 6 & $\begin{array}{l}\text { KancilanFlor } \\
\text { es/anake } \\
\text { Soko }\end{array}$ & $\begin{array}{l}\text { Pacycephala } \\
\text { Mudiga }\end{array}$ & $\begin{array}{l}\text { Flores } \\
\text { endemic }\end{array}$ \\
\hline 7 & Cikrak & $\begin{array}{l}\text { Phylloscopu } \\
\text { s Presbytes }\end{array}$ & $\begin{array}{l}\text { Flores } \\
\text { endemic }\end{array}$ \\
\hline 8 & Otomop alor & $\begin{array}{l}\text { Otomops } \\
\text { Johnstonei }\end{array}$ & $\begin{array}{l}\text { Endangere } \\
\mathrm{d} \quad \text { Flores } \\
\text { endemic }\end{array}$ \\
\hline 9 & Tikus besar & Papag & precarious \\
\hline & & Armdv & $\begin{array}{l}\text { and low } \\
\text { risk }\end{array}$ \\
\hline 10 & Tikus Lawo & $\begin{array}{l}\text { Rattus } \\
\text { Hainaldi }\end{array}$ & $\begin{array}{l}\text { Flores } \\
\text { endemic }\end{array}$ \\
\hline 11 & $\begin{array}{l}\text { Babi hutan } \\
\text { Flores/wawi } \\
\text { ndua }\end{array}$ & Sus heireni & $\begin{array}{l}\text { Flores } \\
\text { endemic }\end{array}$ \\
\hline
\end{tabular}



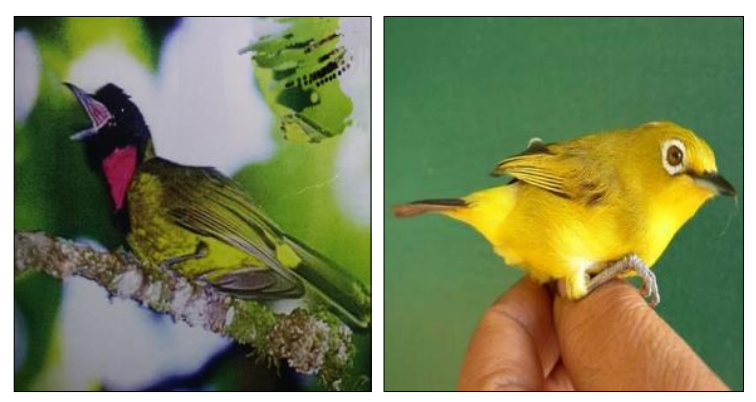

Figure 3. Types of Birds:

Garugiwa(Monarchasp)and

ZosteropspalpebrosaunicaHartert

The above mentioned faunas can be categorized in good conditions in Kelimutu National Park. Food chain in the area also works well. The predators can live normally in a balanced process of food chain. It is the observation of Balai Taman Nasional Kelimutu (2009), this condition evenly occurs in 3 (three) zones of nuclear, ustilisation, and wild zones.This implies that the ecosystem in Kelimutu National Park is stabil and thoroughly kept. Moreover, this area still has various plants that can be supplied for the whole faunas living there.

3. The Potentials of Social Economy and Culture of Local Community in Kelimutu National Park Areas

The forms of dynamic social economy and cultural life of local community in Kelimutu National Park can at least be reflected in 3 (three) important aspects, namely the occupation, belief, and custom. The overview of the three aspects in daily lives of local people may reflect socialeconomy and cultural conditions of the community living in the zone of the park in general. The dynamic forms of the above aspects can be described below.

\section{a. Occupations of Local Community}

Most of local people in Kelimtu National Park work as farmers. They live in 26 scaffolding villages in 5 (five) subdistricts in the areas of the park. Besides working in ricefield, they also work in the garden and cater livestock. Agricultural system implemented in the rice field is both intensification and non intensification, whereas petaniladangused the nomaden system every 3-5 years. After the period, they open new farming land and will go back to previous land after 3-5 years that follow. They go back to previous cultivated land for the reason of the new opened land may decrease its fertility. Nevertheless, some people have their permanent farming land(0,5-1ha) planted with coffee or cocoa. Some plant corn, yam, vegetables (carrot, spinach, bukchoy, cucumber, and peanut), others plant woody plants, such as pecan, атрирu(Eucalyptus urophylla), coconut, and other types of woods.

Besides rice field and farming land, the farmers in the scaffolding villages (26 villages) also utilize their yards, garden, forest, and dike. Besides, people farm some cattles and fish. However, not all local people have yards because of the limited spaces for housing or because the structures of traditional houses do not prioritise yards as in Nduaria and Kelikuku Villages.

Similar condition occurs in the sample villages ( 9 villages) in KelimutuSubdistrict. The local people in these places work in the garden, yards, and forest as their main occupation. In ricefield areas, rice, cassava, and shorgum are planted and cultivated intensificationally in contrast to paddy field that is used for nonintensification. These techniques of cultivication are applicable because of its intensive rainfall (1.615-3.363 $\mathrm{mm} /$ year), its position in relatively flat plateau (671-1107 mdpl). In 2012, the harvests and productions of ricefields in this subdistrict (Kelimutu) reach 5,040 ton in its productive land of $720 \mathrm{Ha}$. Other crops, such as corns, rice field, peanut, and shorgum also have good productivity levels.

Horticultural plants become the preeminent plants in Kelimutu community. The plants are veggies and fruits. In 2013, the production of the veggies was more increased than in 2012. Veggies production in 2012 was $908 \mathrm{Kw}$ and increased to $148,14 \mathrm{Kw}$ and declined to $32,93 \mathrm{Kw}$ in 2013 . The vegetables planted are onion, garlic, potato, cabbage, petsay, carrot, red bean, long bean, chilli, tomato, eggplants, pumpkin,spinach, paprika, and cucumber.Fruits available there are avocados, mangos, rambutan, oranges, guavas, soursoups, papayas, bananas, pinneaples, salak, durian, sawo, and jackfruits. All kinds of veggies and fruits mentioned can be 
consumed in households, and saled in market to provide income for the family. They are usually sold in market, kiosks in the villages, restaurants and hotels, or to directly foreign tourists.

Besides, Kelimutu local people manage the plantation as additional incomes. The plants are coffee, clove, cocoa, hazelnut, vanilla, nutmeg and pepper. These plants are the market commodities and rarely are self consumed. This is a tourist potential that has been progressing in the area, enabling them to have high demands in Kelimutu. Most local people use their land for cattering animals, such as cows, buffaloes, horses, goats, sheeps, pigs, chicken, and ducks. Some are for self consumption, some are for sale, dower, savings, and to help with land cultivation.

The livestocks most local people have are chicken, goats, and pigs. These livestocks are consumable and sometimes can be sold. Cows, horses, and buffaloes are utilized to help in land cultivation, as well as transportation, and custom matters. Generally, these livestocks are very important in occupational life of local people most of whom are farmers. Animal farmings they have are functioned for the sustainability and fertility of ricefield, paddifield, and plantation. So are the tourist objects in Kelimutu National Park. The existences of the local people ranches are indirectly to complete ecotourism attractions there. The activities in the field of agriculture, plantation, and ranch can be the additional attractions other than the nuclear ones as in Kelimutu National Park.

\section{b. Customs and Belief of Society}

Local people in Kelimutu National Park believe in customs and ancestor tradition along with monotheism. The belief on achestors can be seen in the traditional ceremonies and the spirits of the anchestors, whereas monotheism can be the religious teachings taken from bibles. Normally, the beliefs of people are closely related to its agricultural life, but monotheism is more linked to the importance of morality, ethics, and norms of life, and god. In the context of the belief on ancestor spirits, they believe that the spirits of their anchestors still take part in their current lives and the traditional ceremonies they have in particular

http://ojs.unud.ac.id/index.php/eot situation are the ways to communicate this relationship. In their religious context, they believe that everything in their lives is the works of God. Thus, they need to thank God through religious rites held in religious venues to maintain their relationship with God.

The forms of beliefs in traditional ceremonies that people still perform are Jokaju (talisman rites), Mopo (opening new field), KaPoka (eating first harvested rice), Mbama Naka Lea Ria (eating newly harvested rice), Nake Lia Lo'o(harvesting first ginger yields), Poto Lolo (bringing cassava and bitternut into the village), WanggaJawa (carrying corns into the village), Lokalolo(spreading corns in the middle of the village), Lokapare(spreading rice in the center of the village), Depodeo, andNgguaKaUwi (both are ceremonies of eating first harvested cassava and bitternut), Kuwi Pare (thanksgiving), Ngguautabue (eating fresh cassava and bitternut), NgguautawaudanTosa, (both are ceremonies of eating newly harvested rice, cassava leaves, and bitternuts), Poo teu (ceremonies of fighting rats), and Ka Pena (talisman rites).
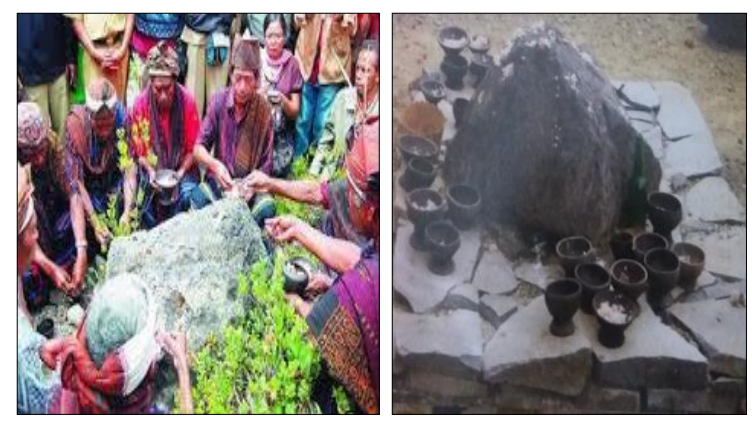

Figure 3. Pa'aLokaCeremony and Patika (offering for the anchestors)

These ceremonies are performed by people in three subdistricts around Kelimutu National Park, such as Detusuko, Wolojita, Ndona, andtwo neighboring subdistricts of WolowaruandLioTimur. Up to present time, the community in those areas still maintains and conducts the ceremonies that now become the cultural tourist attractions in the area. Throughly, the above ceremonies are performed in the time of planting palawijato its harvesting time, or in March to October. The choices of days and dates of the ceremonies depend on each village that is going to hold the ceremonies according to their system of belief. 
In terms of the belief on anchestors spirits, people believe that the spirits of their anchestors still live in certain places in free nature. This belief can be seen in the spirits of their anchestors living in three colored Lake of Kelimutu(Tiwu Ata Bupu, Tiwu Ata Polo, TiwuKo'o Fai Nuwa Muri). This belief is reflected in the ceremonies called PatiKaDuaBapu Ata Mataby serving food to the anchestors spirits. This rite is usually performed in 14 August by Lio-Ende ethnicity mainly. Other ethnicities, like Nga'oand $J a^{\prime}$ 'odo not have this traditions eventhough they are in one area of Ende. In each ceremony, it is the public figure in the village (mosalaki) that leads the rite that is usually done the area of three colored lake in Kelimutu Mountain.

According to the teaching of the anchestors, localpeople believe that the lake of Tiwu Ata Bupu(dark red) is the place where the spirits of the anchestors live. They are believed to live in sacred place there because of their pure souls. In contrast, the anchestors who are sinful and evils live in the dark green lake of Tiwu Ata Polo. The spirits are beleieved to have etrnal punishment in the lake due to their sins and devils. The lake of TiwuKo'o Fai Nuwa Muri is believed to be the place where the spirits of those who died young. People believe that during their lives in the lake, the spirits are fighting to purify their sould in order to live in eternity. The blue wavy lake symbolizes the struggles of the spirits.

In recent years, these forms of belief (traditional rites and ancestor spirit) do not stand alone. They grow together with other monotheist religions, such as Catholic, Moslem, and Christian. One of the examples is the lives of people in Kelimutu Sub-district. The majority is Catholic (17,435 people), Moslem (404 people), and Christian (6 people) (Kelimutu Dalam Angka, 2014). Other religions do not exist in this place, such as Hindi, Buddhist, and Kong Huchu. The same condition also occurs in the scaffolding villages (26 villages) in the area of Kelimutu National Park. Catholic is the majority followed by the other two. Nonetheless, there is no clash between the beliefs of the traditions and religions. People can live harmoniously with these beliefs side by side. Both can

http://ojs.unud.ac.id/index.php/eot complete each other as the meaningful beliefs for local people.

Since Kelimutu National Park was set as one of tourist destinations, the beliefs have become the attractions due to its uniqueness and exotism. They have been cultural tourist attractions together with natural attractions relied. Travel and tourist agents also promote these forms of beliefs as a package of tourist attractions. Through tourism these beliefs have been growing as meaningful resources for local people who believe in them.

\section{c. Customs, Culture, and Tourism Potentials}

As previously highlighted, Kelimutu National Park has rich natural resources containing various traditional and cultural uniqueness. The beliefs of local people in 26 scaffolding villages previously described are one of cultural resources that need to be preserved. These resources are valuably unique and exotic. The custom and traditions are tourist attractions along with natural tourism the park has.

Since the park status of permanent life sanctuary has changed into Kelimutu National Park in 2011, the cultural resources have also developed together with natural tourst objects in the park area. Several of them have been synergistically developed, particularly the traditional villages in the scaffolding areas, namely Traditional Villages of Radaara and Wolotopo in Ndona Subdistrict; Detusoko and Wolodopo in Detusuko Subdistrict; Watugana, Pemo and Woloarain Kelimutu Subdistrict, and others in Subdistricts of Wolojita, Ndona Timur, Wolowaru, Lio Timur, Maurole, Detukeli, Wewaria, and Kotabaru. The tourist objects in these traditional villages are developed with the cultural attractions performed by local people, such as traditional ceremony, custom, art, rites of local people belief.

Additionally, Kelimutu National Park has also developed other interesting tourist destination, such as tourist village of National Park; Agro-ecotourism and tracking. Arboretum with various kinds of birds for study tour and recreation; Insectarium and Herbarium for study tour and research, and 
Dutch herited houses for historical tour. The tourist objects are developed in line with the development of natural tourist destination, such as 3 (three) colored Lake of Kelimutu, hot spring, waterfall, herbal plants, scarce flora and fauna, diverse wild animals and endemic reptiles in Kelimutu National Park.

Many different cultural and natural tourist objects are in a developmental term, that is to say a tourist destination of Kelimutu National Park. Natural and cultural tourist objects are integrated to Kelimutu National Park, eventhough the natural objects in Kelimutu National Park are more attractive than its cuiltural attractions. As commented by most of visitors of the park, they are more interested in natural scenery and uniqueness of the three coloroured lake on the top of Kelimutu Mountain.

Lately, these tourist objects have been developed and attracted many domestic and foreign tourists. Nonetheless, there are many things that need to be fixed to manifest a tourist destination that can give comforts and satisfaction for the visitors. Those things, such as the traffic in peak touring season, limited parking lot, less available tour guides, limited directory, less maintained common facilties (toilets), the unfriendly attitudes of local vendors, are the annoyances for visitors. For the future, its management need to be improved so that the tourist objects are more quality and appealing to visitors of Kelimutu National Park objects.

\section{Conclusion}

The potential of Kelimutu National Park is not only as as natural tourist destination but also a cultural tourist destination with the local traditions. Besides the attractions of three colored Lake of Kelimutu, there are also flora and fauna attractions. Rivers sourced in Kelimutu Mountain are also natural tourism potentials. Cultural potentials are in the forms of traditional villages and its traditional ceremonies. Moreover, there are several man made attractions, namely tourist villages, arboretum, insectarium, herbarium, agrotourism, and Dutch Herited Houses.
Those assets may still be considered simple and needed to be developed. The collaboration of all parties to manifest this vision is required. Those parties are Government of Ende Regency, the Office of Kelimutu National Park, the communities of four nuclear villages (public figures, religious figures, head of village, and mosalaki) as well as the representatives of 26 villages and nongovernment organisations. Therefore, the current situation can be in line with the expectation of society so that they can participate actively.

\section{References}

Damanik, J. and Teguh, F. (2012) Manajemen Destinasi Pariwisata, Sebuah Pengantar Ringkas. Yogyakarta: Kepel Press.

\begin{tabular}{ccc} 
Direktur Jendral Pengembangan & Destinasi \\
Pariwisata & $(2010)$ & Pedoman \\
Pembentukandan & Pengembangan \\
Destination & \multicolumn{2}{c}{ Management } \\
Organization & $($ DMO). & Jakarta: \\
Kemenpar. & &
\end{tabular}

Fandeli, C. (2002) Perencanaan Kepariwisataan Alam. Yogyakarta: FakultasKehutanan UGM.

Nugroho, I. (2011) Ekowisata dan Pembangunan Berkelanjutan. Cetakan Pertama. Jakarta: Pustaka Pelajar.

Page, S. J. and Dowling, K. R. (2001) Ecotourism. Pearson Education Limited. United Kingdom.

Supriatna, J. (2014) Berwisata Alam di Taman Nasional.Yayasan Obor Indonesia. Jakarta.

Wiratno, D., Indriyo, A., Syarifudin and Kartikasari, A. (2004) Berkaca di Cermin Retak (Refleksi Konservasi dan Implikasi Bagi Pengelolaan Taman Nasional). Jakarta: FoReST Press. 